\title{
The Relationship between State of Maturity and Chemical Composition of the Whiting, Gadus merlangus L.
}

\author{
By \\ H. O. Bull, B.Sc., \\ Marine Biological Laboratory, Plymouth.
}

With 2 Figures in the Text.

THIs research was undertaken at the instigation of Mr. E. Ford, who, during other investigations, had noticed great fluctuations in the relative size of the liver in the whiting. It is likely that the results obtained are representative of gadoids generally, when subject to similar conditions. In an account of the Irish Sea Cod Fishery, 1921-3, by Johnstone, Smith and Fleming (1), a series of analyses are given, which, though showing wide variation, indicate that there is no seasonal variation in the composition of the Manx cod-contrary to the authors' expectations. There are in addition, several accurate, detailed descriptions of correlated tissue changes in other fishes, notably the herring, salmon and eel, and it should be economically valuable to have a similar record of all the staple food fishes.

For the whiting, such a study needs more preliminary data than are at present available.

Age determination in this species, by means of scales, has, in these waters, been found difficult, though in Icelandic waters, where there is a very well marked bi-annual seasonal change of conditions, it is, according to Saemundsson (2), quite possible. In the present investigation it has not been attempted.

The effect of food at different stages of digestion is another unknown factor exerting probably a large influence, and requiring a systematic enquiry. Whiting have usually the habit of ejecting the whole of their stomach contents, when caught in the trawl, and it is difficult to get an accurate idea of the food they may have recently consumed. When any food was found present, its amount and nature was noted. (See Appendix to Table 4, p. 218).

Lastly, so far as I know, no one has given a description of the developmental changes in the ripening gonads. I have therefore drawn up the 
following arbitrary scheme of the various stages, which agrees very closely with that given by Graham (3) for the Cod.

(a) Females.

DEFINITIONS OF MATURITY STAGES.

As in the cod, a classification can be drawn up based mainly on changes in colour of the ovary. The following stages have been adopted :-

I. Immature fish. Ovaries not more than $2.5 \mathrm{~cm} . \times 0.5 \mathrm{~cm}$.- frequently a narrow ribbon, only with difficulty to be distinguished from testis in a similar stage. Eggs microscopic. Colour, whitish or pinkish : becomes orange before maturing.

II. Mature fish, in normal resting condition, after complete recovery from previous spawning (if any). Ovaries approximately $5 \mathrm{~cm}$. $\times 1 \mathrm{~cm}$. Eggs microscopic. Colour, dull to bright orange.

IIA. "Spents." Ovaries pinkish white, flaccid, shrunken, with perhaps a few undischarged, degenerating eggs.

III. Mature fish, ripening. Ovaries enlarging, not less than $5 \mathrm{~cm} . \times 1 \mathrm{~cm}$. Eggs visible to the naked eye: opaque. Colour, buif, pinkishbuff, or flesh.

IV. Ovaries much enlarged and distended - almost ripe. Eggs nearly all transparent. Colour, dark to light cream.

V. Spawning fish. No examples obtained.

(b) Males.

These are far more difficult to classify than the females.

I. Immature fish. Testes very minute; a very thin, narrow translucent, whitish ribbon. Invariably characteristic of fish in the first year of life, and of older fishes not previously spawned or approaching spawning.

II. Mature fish in normal resting condition. Testes slightly lobed and only lightly coiled: much less translucent than I., with a few opaque, whitish patches.

IIA. "Spents." Indistinguishable from II., and therefore not used in practice.

III. Mature fish ripening. Testes more pronounced, more strongly coiled, and lobes fatter. Colour mainly opaque-white. Rarely less than $5 \mathrm{~cm} . \times 1.25 \mathrm{~cm}$.

IV. Testes strongly lobed and much convoluted, with a completely opaque, milky-white appearance.

V. Spawning. Milt running. No examples obtained. 


\section{Preparation of Material.}

The fish used were caught off Plymouth by the Research Steamer Salpa, landed usually between 3.0 p.m. and 5.0 p.m., and brought at once to the chemical laboratory. If a large number of fish were landed, an adequate sample was taken of the various sizes represented, whilst if a small collection only was obtained, the whole was utilised.

The fish were wiped free from all adherent moisture and slime, immediately measured, and weighed. The livers and gonads were dissected out, freed from superficial body fluid and blood by means of blottingpaper, and weighed at once. For the analysis of the flesh, the whole of one side of the fish was used, after separating the muscle substance from the vertebral column and skin. Except in the very largest fish, the full amount of this flesh was used, so that there is no question of errors in sampling-even supposing these to be significant in flesh so homogeneous as that of the whiting.

Fish of similar size and like state of maturity were picked out from the sample and grouped together in the manner shown in Table 4. The analyses of liver and flesh were made upon each group of fish, taken collectively, and treated as one.

\section{Methods of Analysis.}

These need not be given in detail, as they differed little from standard practice, but a few notes are necessary.

Water. The weighed portions, representing usually 15-20 grms., but frequently more or less, were dried in tared beakers at $100^{\circ} \mathrm{C}$. to a constant weight. This required from 36 to 48 hours - muscular tissue requiring much less time than the liver. The loss of weight was checked by weighing the solids after extraction with ether.

Fat. The quantity remaining after drying was extracted with 250 c.c. anhydrous ether in a 100 c.c. Soxhlet extraction apparatus for 6 to 8 hours. The ether was distilled off from the ethereal extract and the residue dried at $100^{\circ} \mathrm{C}$. in a current of dry $\mathrm{CO}_{2}$ to a constant weight, taking the usual precautions. The error arising from oxidation, though by no means negligible in accurate work, is sufficiently small to be neglected here, in view of the errors inherent in sampling fresh tissues.

Protein. This is here regarded as total nitrogen $\times 6 \cdot 25$.

The Kjeldahl-Gunning method was followed with only minor variations. Estimations were made on 0.2 or $0.5 \mathrm{grm}$. of the dried, fat-free material remaining after the drying and subsequent extraction with ether.

Several workers on biological problems have doubted the validity of the factor $6 \cdot 25$, when applied to fish protein, though their views are very conflicting. Atwater, Johnstone, Bruce (4) and others contribute to the NEW SERIES,-VoL. Xv. No. 1. FEBRUARY, 1928. 
discussion. The factor 6.25 is used here, however, in the belief that it is sufficiently correct for our purpose, and it must be stated that most of the arguments put forward against its use are not very convincing. For instance, in the Report of the Lancashire Sea Fisheries Laboratory, Vol. 37, page 120 , it is regarded as too high, on the ground that the totals, " water, fat, ash and proteid (N. $\times 6 \cdot 25)$," came to considerably more than $100 \%$, when it would be much more reasonable to cast doubt on the larger variables, water and fat.

Bruce (4), on the other hand, mentions that there is some uncertainty about the application of the factor $6 \cdot 25$, in the conversion of total nitrogen into fish protein, but does not deal with it from the point of view of protein constitution, which is the real issue.

In using carbon tetrachloride for the extraction of fats, some proteid matter is carried through, and he mainly confines his discussion to the correction of this loss. With the use of this fat-solvent and his procedure, which is similar to Johnstone's, he therefore suggests a higher factor. The remedy would be the use of a different fat-solvent : e.g. ether.

Plimmer (5), however, states that this conversion factor is correct, or nearly so, for the proteins of the muscular tissue of fishes, but not for those derived from other sources. Until it is known what proteins are present in the livers and tissues of the fishes concerned, it seems futile to. argue about the bearing of unexpected analytical results on the application of this factor for the conversion of total nitrogen into fish protein. This is particularly so with the herring, in view of the possibility that clupein, whose percentage of nitrogen is $31 \cdot 68$, and which is normally found in ripe sperms, may be present in other parts. Likewise, in any fish, the presence of protamines would necessitate a change in the factor.

$A s h$. Non-volatile mineral matter left on ignition of the dried, fat-free material at bright red heat.

Carbohydrates. These were not estimated, owing to the impossibility of carrying out large numbers of estimations in the time available. It is. probable that the " undetermined" is mainly carbohydrates, though this has not been confirmed. Accepting this as true for practical purposes, it would seem that the amount in the liver varies more or less haphazardly, and, as suggested by Kilburn and Macleod (6), very likely varies with the season, feeding conditions, and possibly with many other factors.

\section{The Results.}

The results are expressed in the form of a comprehensive table (Table 4, p. 216), which includes all the relevant information : males, females, and "very small" fish being separately treated. Besides the material there presented, the relationships of length and weight of fish respectively to 
weight of liver were also worked out; in both cases the correlation is very slight. Neither is there any strong relationship between the ratio weight of fish weight of liver and the state of maturity.

The results in the whiting thus agree with those in the cod-although Graham (3) argues, albeit with insufficient data, that an increase in the value of $\mathrm{K}$, the "condition constant" of the fish, should in general be accompanied by an increase in the "condition constant" of the liver, i.e. $-100 \times$ wt. of liver : length of fish ${ }^{3}$.

The main point of interest that the results show, however, is that whereas in the trade category " fatty" fish, salmon, herring, etc., most of the material necessary for gonad formation seems to be derived from the longitudinal muscles of the body wall, in the whiting, the composition of the muscular tissue remains remarkably constant, and it is the liver which undergoes great changes in composition, as may be clearly seen by a study of Table 4. Even the isolated analysis of the flesh given by Plimmer (5), referring to a fish from unknown locality, is very similar to the analyses given by me, of which the average values are shown in the table below :-

\section{TABLE 1.}

\section{Composition of Whiting Muscle.}

\begin{tabular}{|c|c|c|c|c|}
\hline & & Average of & s of prese & nt investigation. \\
\hline & Plimmer. & Females. & Males. & $\begin{array}{c}\text { Very small. } \\
\text { Sex doubtful. } \\
\text { Av. size } 12 \cdot 4 \mathrm{~cm} .\end{array}$ \\
\hline Water & $80 \cdot 4$ & $80 \cdot 5$ & $80 \cdot 0$ & $80 \cdot 2$ \\
\hline Fat . & $0 \cdot 2$ & $0 \cdot 3$ & $0 \cdot 3$ & $0 \cdot 3$ \\
\hline Protein & $17 \cdot 7$ & $16 \cdot 4$ & $17 \cdot 1$ & $16 \cdot 7$ \\
\hline Ash . & $1 \cdot 1$ & $1 \cdot 3$ & $1 \cdot 4$ & $1 \cdot 3$ \\
\hline Undetermined & $0 \cdot 6$ & $1 \cdot 5$ & $1 \cdot 2$ & $1 \cdot 5$ \\
\hline & $100 \cdot 0$ & $100 \cdot 0$ & $100 \cdot 0$ & $\overline{100 \cdot 0}$ \\
\hline
\end{tabular}

In the whiting then, it appears that there is a direct relationship between the state of maturity and the gross chemical composition of the liver. This is best illustrated by giving the ratio of fat to water in the liver, and the following table gives the mean value of this figure corresponding to the various stages in development of the gonads. It is depicted graphically in Fig. 1, and it will be noted that there is some difference in the sexes, both with regard to the percentage of fat generally, and the rate at which its increase and decrease in the liver takes place. 


\section{TABLE 2.}

The Relationship between the Stage of Maturity and Amount of Fat in the Liver of the Whiting.

(a) Females.

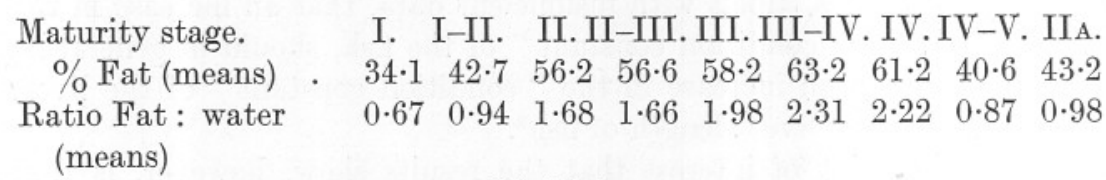

(b) Males.

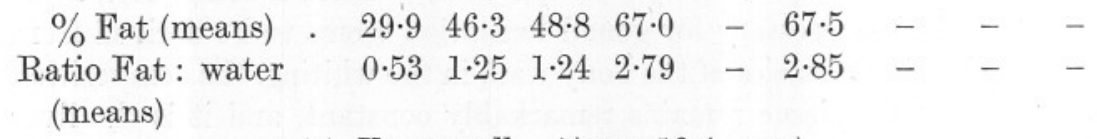

(c) Very small. (Aver. 12.4 cms.).

$\begin{array}{cccccccccc}\text { \% Fat (means) } & 14 \cdot 1 & - & - & - & - & - & - & - & - \\ \text { Ratio Fat: water } & 0 \cdot 21 & - & - & - & - & - & - & - & - \\ \text { (means) }\end{array}$

As the numerical designation of the maturity stages is artificial, it is only natural that there should be a wide variation within the classes. For instance, in the IIA class, the ratio would depend on how far the fish had recovered from spawning, which by ordinary observation is not ascertainable.

The ratios in the respective classes of immature Stage I, immature female Stage I-II, and the female in normal resting condition Stage II, must obviously overlap greatly - depending on the precocity, retardation of development, or nutrition of the fish. The only other figure (amongst the females) calling for comment is the ratio of 1.577 in Stage III-IV (February 1st, 1927). It is quite reasonable to suppose that the fishes which gave this figure were in a much later stage than that in which they were placed-a point of view that is quite permissible from Fulton's statement ( $\boldsymbol{y})$ that the eggs mature in successive crops, which, as they mature, are shed.

I have already mentioned the difficulty of classifying the maturity stages of the males, so that here also it is not surprising to find an occasional exceptional figure: indeed, even in quite immature fish functional sperms are present. The testes do not undergo so great a development as the ovaries - a fact which is reflected in the higher percentage of fat in the liver at the stages when ripening is initiated. But as the testes become relatively much enlarged and convoluted, the fat content of the liver becomes gradually reduced, and although it seems impossible to separate "Spents" from "Normal resting males," a loss of fat seems to 
occur in much the same way as is shown more clearly in the female. The ratio fat: water of $0 \cdot 21$ given by the immature fish, is made the first point on the graphs of both sexes.

The results appear to indicate that with growth both in size and maturity the quantity of fat in the liver becomes relatively greater, reaching its maximum a little time after the gonads have begun to ripeni.e. about Stage III. Thereafter, as the gonads increase in size, and the

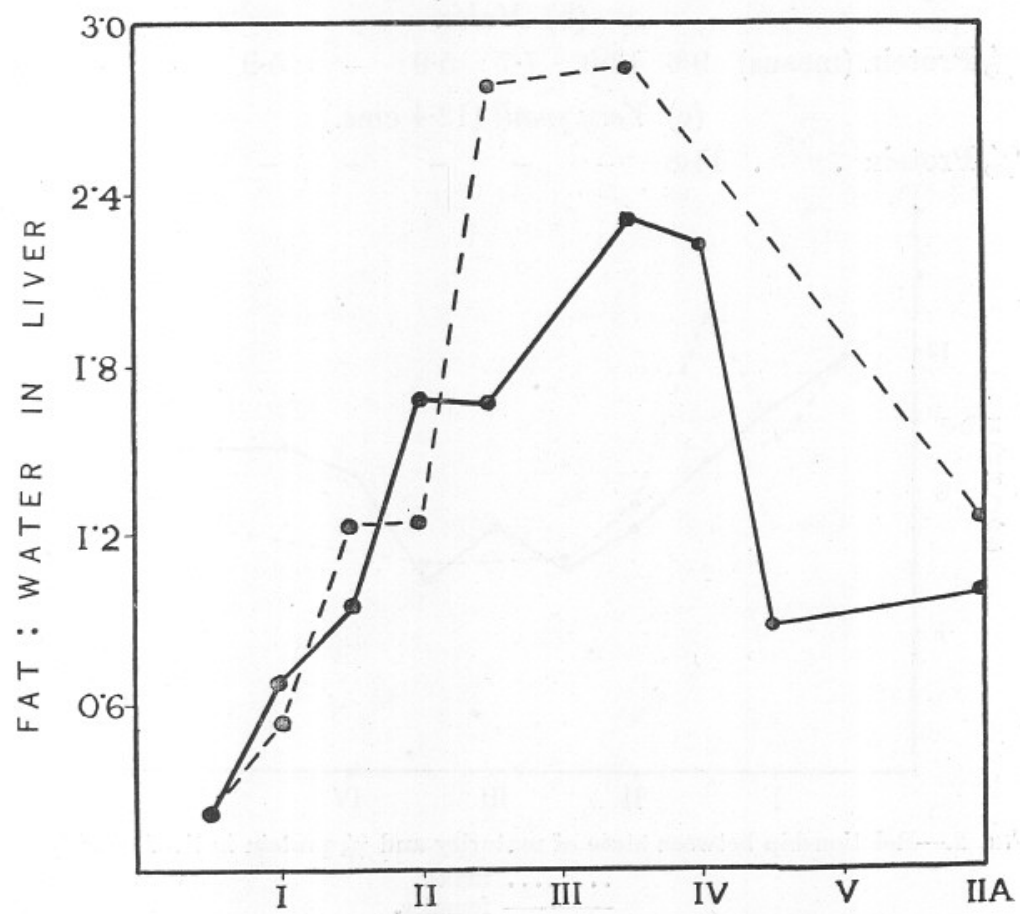

FIG. 1.--Relationship between state of maturity and ratio of fat : water in the liver of the whiting.

....... males.

drain in metabolism becomes felt, the fat in the liver becomes rapidly less, reaching a minimum in spent fish : the cycle being then repeated as before. On the other hand, the muscle substance remains approximately unchanged-which, of course, accounts for the palatability of the flesh in recently spawned fishes not being impaired.

Of the other substances in the liver it is noticeable that the amount of protein is also correlated with age and maturity, but that, unlike the fat content, it becomes less with increasing stages of maturity. The average value of the protein content of the liver for each maturity class is shown in the following table, and is indicated graphically in Fig. 2. 


\section{TABLE 3.}

Average Protein Content of the Liver of the Whiting in Relation to Maturity.

(a) Females.

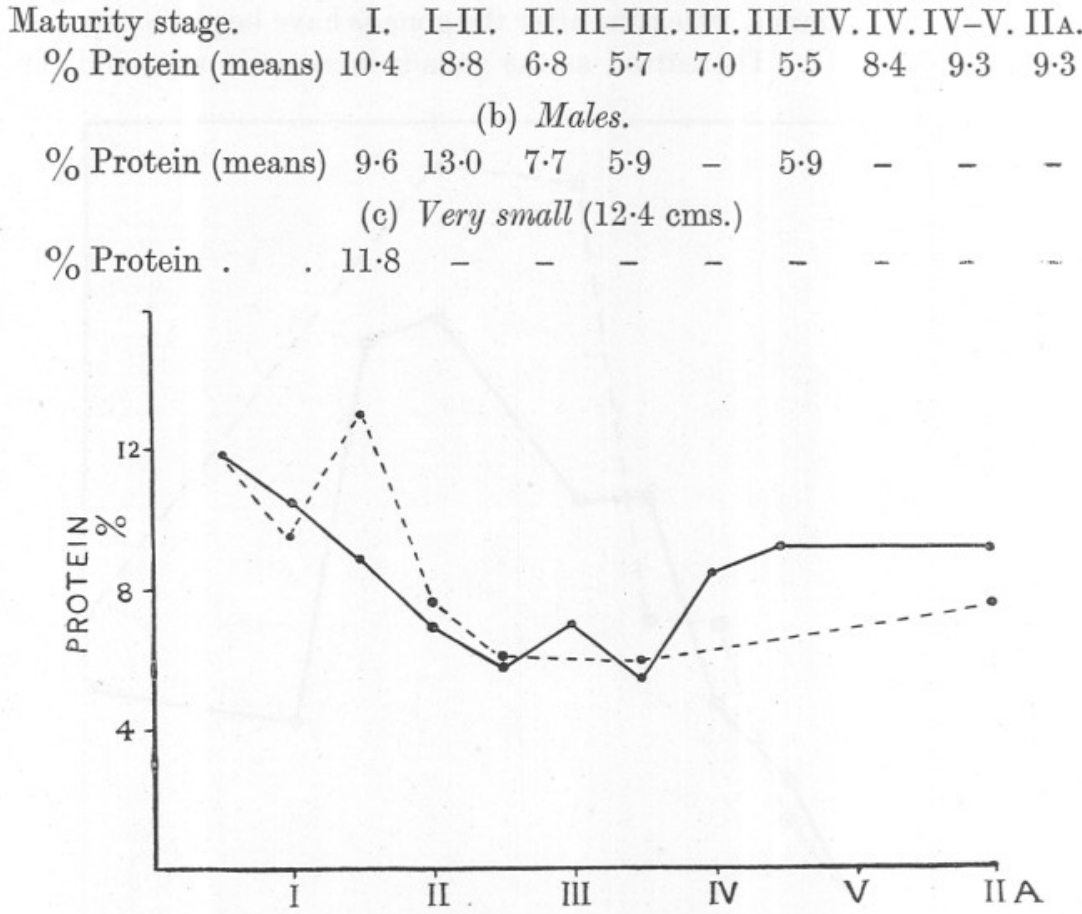

Frg. 2.-Relationship between state of maturity and \% protein in liver of whiting. $\underline{\ldots \ldots}$ males.

It appears quite definite then, that immature fishes have a decidedly higher protein content in the liver than mature fishes. This diminishes until commencement of ripening, and then becomes gradually higher, reaching its highest amongst mature fishes in the "Spent" stages.

The changes undergone by the liver, as outlined above, are almost parallel to those recorded by Bruce in the muscle of the herring. $\mathrm{He}$ also found a like decrease in fat content of the liver of the herring correlated with the growth of the gonads, and states that the liver of the male, as in the case of whiting, is richer in fat than that of the female.

He concludes that the metabolic demands of the developing gonads are met, in the first instance, by the fatty reserves of the liver. There is no doubt whatever that this occurs also in the whiting.

Other species of fish investigated up to the present have not yielded 
much evidence upon this point, so that it cannot as yet be stated that it is general amongst fishes. Storage, and subsequent metabolic transference of materials, especially those contributing to the structure of lecithins, may occur in other parts of the digestive tract besides the liver.

I wish to thank my wife for her valuable help, and Dr. E. J. Allen, Dr. W. R. G. Atkins, and Mr. E. Ford for their helpful criticism.

\section{SUMMARY.}

In the whiting, no significant changes occur in the composition of the muscle substance, either throughout the year, or with increasing age, or during ripening of the gonads.

The amount of fat in the liver is very low in immature fishes, increasing greatly with age, and reaching its maximum just after the commencement of the ripening of the gonads. It then falls off, reaching its lowest value amongst mature fishes in the "Spent" stages. Males are richer in liver fat than females.

Immature fish have a decidedly higher protein content in the liver than have mature fish.

\section{REFERENCES.}

1. Johnstone, Jas., Smith, W. C., and Fleming, R. A. The Irish Sea Cod Fishery of 1921-3. Trans. Liverpool Biol. Soc., Vol. 37. 1923.

2. Saemundsson, B. On the Age and Growth of the Whiting in Icelandic Waters. Med. Fra. Komm. Havunders. Ser. Fisk., Bd. VIII, No. 1. 1925.

3. Graham, M. The Annual Cycle in the Life of the Mature Cod in the North Sea. Fishery Investigations, England, Series II, Vol. VI, No. 6. 1923.

4. Bruce, J. R. Changes in the Chemical Composition of the Tissues of the Herring in Relation to Age and Maturity. Biochem. Journ., Vol. 18, Nos. 3 and 4. 1924.

5. Plimmer, R. H. A. Analyses and Energy Values of Foods. H.M. Stationery Office. 1921.

6. Kilburn, L. G., and Macleod, J. J. R. Observations on the Glycogen Content of Certain Invertebrates and Fishes. Quart. Journ. Exp. Physiol., 12, p. 317.

7. Fulton, T. W. Fishery Board for Scotland 9th Annual Report, 3, p. 257. 1891. 
TABLE 4.

Particulars of Fish Taken for Analysis, and the Complete Analyses thereof.

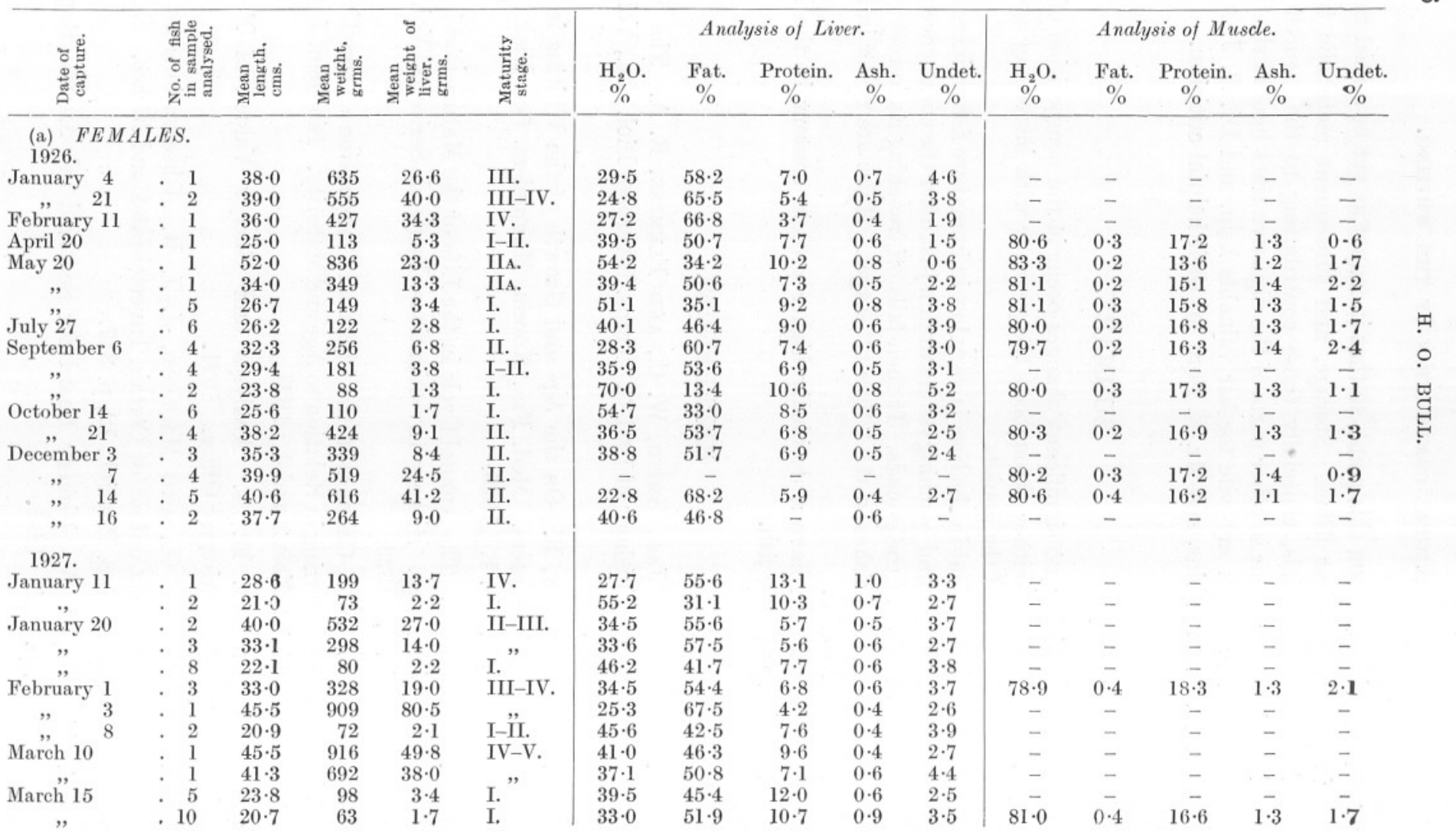




\begin{tabular}{|c|c|c|c|c|c|c|c|c|c|c|c|c|c|c|c|}
\hline April 5 & . 5 & $19 \cdot 8$ & 53 & $1 \cdot 0$ & I. & $55 \cdot 5$ & $31 \cdot 3$ & $9 \cdot 5$ & $0 \cdot 6$ & $2 \cdot 1$ & - & - & - & - & - \\
\hline , & . 3 & $26 \cdot 3$ & 129 & 42 & I-II. & $39 \cdot 8$ & $47 \cdot 3$ & $10 \cdot 7$ & 0.7 & $1 \cdot 6$ & - & - & - & - & - \\
\hline , & . 2 & $28 \cdot 0$ & 154 & $4 \cdot 7$ & IV $-\mathrm{V}$. & $61 \cdot 8$ & $24 \cdot 7$ & $11 \cdot 2$ & $0 \cdot 6$ & $1 \cdot 7$ & - & - & - & - & - \\
\hline April 27 & . 3 & $17 \cdot 9$ & 38 & $0 \cdot 4$ & I. & $64 \cdot 0$ & $14 \cdot 5$ & $17 \cdot 0$ & $1 \cdot 1$ & $3 \cdot 4$ & - & - & - & - & - \\
\hline & . 5 & $25 \cdot 2$ & 113 & $2 \cdot 1$ & I. & $54 \cdot 2$ & $31 \cdot 7$ & $10 \cdot 2$ & $0 \cdot 8$ & $3 \cdot 1$ & - & - & - & - & - \\
\hline May 4 & . 3 & $27 \cdot 2$ & 142 & $1 \cdot 9$ & I-II. & $66 \cdot 0$ & $19 \cdot 3$ & $10 \cdot 9$ & $0 \cdot 7$ & $3 \cdot 1$ & - & - & - & - & - \\
\hline,$\quad 5$ & . 1 & $40 \cdot 8$ & 485 & $15 \cdot 2$ & IIA. & $47 \cdot 0$ & $43 \cdot 2$ & $7 \cdot 5$ & $0 \cdot 6$ & $1 \cdot 6$ & - & - & - & - & - \\
\hline,$\quad 13$ & . 4 & $33 \cdot 9$ & 283 & $6 \cdot 5$ & IIA. & $38 \cdot 3$ & $45 \cdot 0$ & $12 \cdot 4$ & $0 \cdot 8$ & $3 \cdot 5$ & - & - & - & - & - \\
\hline $\begin{array}{l}\text { (b) MALES } \\
1926 .\end{array}$ & & & & & & & & & & & & & & & \\
\hline January 4 & . 1 & $27 \cdot 0$ & 264 & $8 \cdot 7$ & II-III. & $18 \cdot 9$ & $72 \cdot 6$ & $3 \cdot 8$ & $0 \cdot 4$ & $4 \cdot 3$ & - & - & - & - & - \\
\hline,$\quad 21$ & . 1 & $28 \cdot 3$ & 204 & $11 \cdot 8$ & ," & $18 \cdot 0$ & $69 \cdot 7$ & $9 \cdot 4$ & $0 \cdot 8$ & $2 \cdot 1$ & - & - & - & - & - \\
\hline & . 1 & $27 \cdot 0$ & 139 & $6 \cdot 1$ & ," & $22 \cdot 6$ & $71 \cdot 2$ & $5 \cdot 0$ & $0 \cdot 2$ & $1 \cdot 0$ & - & - & - & - & - \\
\hline February 11 & . 1 & $21 \cdot 0$ & 74 & $1 \cdot 7$ & II." & $31 \cdot 1$ & $44 \cdot 1$ & - & - & - & - & - & - & - & - \\
\hline April"20 & · 1 & $30 \cdot 5$ & 236 & $11 \cdot 9$ & III-IV. & $25 \cdot 1$ & $68 \cdot 6$ & $4 \cdot 2$ & $0 \cdot 4$ & $1 \cdot 7$ & - & - & - & - & - \\
\hline $\begin{array}{l}\text { April } 20 \\
\text { June 24 }\end{array}$ & · 6 & $20 \cdot 0$ & 60 & $1 \cdot 6$ & I. & $52 \cdot 2$ & $34 \cdot 2$ & $7 \cdot 8$ & $0 \cdot 7$ & $5 \cdot 1$ & $80 \cdot 7$ & $0 \cdot 5$ & $15 \cdot 9$ & $1 \cdot 3$ & $1 \cdot 6$ \\
\hline $\begin{array}{l}\text { June } 24 \\
\text { July } 27\end{array}$ & .10 & $24 \cdot 8$ & 108 & $2 \cdot 4$ & I. & $47 \cdot 5$ & $39 \cdot 9$ & $8 \cdot 5$ & $0 \cdot 7$ & $3 \cdot 4$ & $80 \cdot 1$ & $0 \cdot 2$ & $16 \cdot 6$ & $1 \cdot 4$ & $1 \cdot 7$ \\
\hline July 26 & $\begin{array}{l}1 \\
. \quad 2\end{array}$ & $23 \cdot 8$ & 99 & $3 \cdot 4$ & I. & $40 \cdot 1$ & $46 \cdot 4$ & $9 \cdot 0$ & $0 \cdot 6$ & $3 \cdot 9$ & $80 \cdot 0$ & $0 \cdot 2$ & $17 \cdot 2$ & $1 \cdot 3$ & $1 \cdot 1$ \\
\hline & $\begin{array}{l}2 \\
. \quad 2\end{array}$ & $28 \cdot 7$ & $\begin{array}{r}198 \\
88\end{array}$ & $11 \cdot 8$ & II. & $43 \cdot 6$ & $44 \cdot 6$ & $5 \cdot 4$ & $0 \cdot 5$ & $5 \cdot 9$ & $79 \cdot 8$ & $0 \cdot 2$ & $17 \cdot 1$ & $1 \cdot 2$ & $1 \cdot 7$ \\
\hline $\begin{array}{l}\text { September } 6 \\
\text { October } 13\end{array}$ & $\begin{array}{l}2 \\
. \quad 6\end{array}$ & $\begin{array}{l}24 \cdot 0 \\
32 \cdot 6\end{array}$ & $\begin{array}{r}88 \\
256\end{array}$ & $\begin{array}{r}2 \cdot 0 \\
10 \cdot 2\end{array}$ & I. & $\begin{array}{l}70 \cdot 0 \\
18 \cdot 9\end{array}$ & $\begin{array}{l}13 \cdot 4 \\
72 \cdot 0\end{array}$ & $\begin{array}{r}10 \cdot 6 \\
5 \cdot 7\end{array}$ & $\begin{array}{l}0 \cdot 8 \\
0 \cdot 3\end{array}$ & $\begin{array}{l}5 \cdot 2 \\
3 \cdot 1\end{array}$ & $\begin{array}{l}80 \cdot 0 \\
79 \cdot 7\end{array}$ & $\begin{array}{l}0 \cdot 3 \\
0 \cdot 4\end{array}$ & $\begin{array}{l}17 \cdot 3 \\
17 \cdot 4\end{array}$ & $\begin{array}{l}1 \cdot 3 \\
1 \cdot 4\end{array}$ & $\begin{array}{l}1 \cdot 1 \\
1 \cdot 1\end{array}$ \\
\hline December 3 & . 4 & $31 \cdot 8$ & 231 & $4 \cdot 8$ & II. & $42 \cdot 0$ & $41 \cdot 7$ & $11 \cdot 3$ & $0 \cdot 8$ & $4 \cdot 2$ & - & - & - & - & - \\
\hline , $\quad 7$ & . 5 & $29 \cdot 8$ & 176 & $6 \cdot 6$ & II-III. & - & - & - & - & - & $80 \cdot 2$ & $0 \cdot 5$ & $16 \cdot 7$ & $1 \cdot 5$ & $1 \cdot 1$ \\
\hline ", & . 5 & $18 \cdot 6$ & 44 & $0 \cdot 9$ & & $56 \cdot 8$ & $29 \cdot 4$ & $10 \cdot 1$ & $0 \cdot 7$ & $3 \cdot 0$ & $81 \cdot 0$ & $0 \cdot 4$ & $14 \cdot 7$ & $1 \cdot 5$ & $2 \cdot 4$ \\
\hline , 16 & . 3 & $24 \cdot 5$ & 99 & $1 \cdot 8$ & I-II. & $36 \cdot 9$ & $46 \cdot 3$ & $13 \cdot 0$ & $0 \cdot 8$ & $3 \cdot 0$ & - & - & - & - & - \\
\hline $\begin{array}{l}1927 . \\
\text { January }\end{array}$ & & & & & & & & & & & & & & & \\
\hline January 11 & . 5 & $27 \cdot 4$ & 165 & $5 \cdot 9$ & II-III. & $35 \cdot 2$ & $53 \cdot 3$ & $6 \cdot 7$ & $0 \cdot 5$ & $4 \cdot 3$ & - & - & - & - & - \\
\hline ", & · 6 & $21 \cdot 1$ & 70 & $1 \cdot 6$ & I. & $55 \cdot 2$ & $31 \cdot 1$ & $10 \cdot 3$ & $0 \cdot 7$ & $2 \cdot 7$ & - & - & - & - & - \\
\hline , 20 & . 5 & $30 \cdot 3$ & 233 & $16 \cdot 3$ & II-III. & $25 \cdot 4$ & $68 \cdot 0$ & $4 \cdot 5$ & $0 \cdot 3$ & $1 \cdot 8$ & - & - & - & - & - \\
\hline February 1 & . 1 & $34 \cdot 6$ & 368 & $15 \cdot 6$ & III-IV. & $23 \cdot 9$ & $63 \cdot 3$ & $9 \cdot 0$ & $0 \cdot 7$ & $3 \cdot 1$ & $77 \cdot 5$ & $0 \cdot 5$ & $19 \cdot 6$ & $1 \cdot 5$ & $0 \cdot 9$ \\
\hline $\begin{array}{ll}, \quad 3 \\
\end{array}$ & . 3 & $27 \cdot 2$ & 175 & $13 \cdot 3$ & III-IV. & $22 \cdot 1$ & $70 \cdot 6$ & $4 \cdot 5$ & $0 \cdot 2$ & $2 \cdot 6$ & - & - & - & - & - \\
\hline March $15{ }^{8}$ & · 4 & $21 \cdot 2$ & 80 & $2 \cdot 9$ & II. & $38 \cdot 5$ & $51 \cdot 3$ & $4 \cdot 7$ & $0 \cdot 5$ & $5 \cdot 0$ & - & - & - & - & - \\
\hline $\begin{array}{l}\text { March } 15 \\
\text { May } 4\end{array}$ & $\begin{array}{l}. \quad 6 \\
\cdot \quad 3\end{array}$ & $\begin{array}{l}20 \cdot 3 \\
26 \cdot 5\end{array}$ & $\begin{array}{r}61 \\
129\end{array}$ & $\begin{array}{l}1 \cdot 2 \\
2 \cdot 4\end{array}$ & I. & $\begin{array}{l}60 \cdot 9 \\
66 \cdot 0\end{array}$ & $\begin{array}{l}25 \cdot 2 \\
19 \cdot 3\end{array}$ & $\begin{array}{r}9 \cdot 2 \\
10 \cdot 9\end{array}$ & $\begin{array}{l}0 \cdot 7 \\
0.7\end{array}$ & $4 \cdot 0$ & $81 \cdot 0$ & $0 \cdot 4$ & $16 \cdot 6$ & $1 \cdot 3$ & $0 \cdot 7$ \\
\hline,$\quad 13$ & . 2 & $33 \cdot 7$ & 271 & $9 \cdot 0$ & II. & $\begin{array}{l}66 \cdot 0 \\
35 \cdot 4\end{array}$ & $\begin{array}{l}19 \cdot 3 \\
53 \cdot 9\end{array}$ & $\begin{array}{r}10 \cdot 9 \\
8 \cdot 5\end{array}$ & $\begin{array}{l}0.7 \\
0.4\end{array}$ & $\begin{array}{l}3 \cdot 1 \\
1 \cdot 8\end{array}$ & - & - & - & - & $\overline{-}$ \\
\hline $\begin{array}{l}\text { (c) VERY } \\
1926 .\end{array}$ & $S M A L$ & $S E X$ & $D O U$ & $U L$. & & & & & & & & & & & \\
\hline July 5 & . 23 & $13 \cdot 1$ & $16 \cdot 8$ & $0 \cdot 35$ & & $60 \cdot 1$ & $23 \cdot 3$ & $10 \cdot 4$ & $0 \cdot 8$ & $5 \cdot 5$ & $79 \cdot 7$ & $0 \cdot 3$ & $17 \cdot 0$ & $1 \cdot 3$ & $1 \cdot 7$ \\
\hline September 7 & .10 & $11 \cdot 1$ & $9 \cdot 5$ & $0 \cdot 09$ & & $76 \cdot 8$ & $4 \cdot 9$ & $13 \cdot 1$ & $1 \cdot 0$ & $4 \cdot 3$ & $80 \cdot 6$ & $0 \cdot 3$ & $16 \cdot 4$ & $1 \cdot 4$ & $1 \cdot 3$ \\
\hline
\end{tabular}




\section{APPENDIX TO TABLE 4.}

Stomach Contents.

Number of stomachs containing each item given in brackets.

(a) Females. Stages I and I-II. 76 Specimens.

Empty (51), "Fish "* (18), Sprat (1), Gobius minutus (1), Mysids (1), Upogebia sp. (2), Larval Gadoids (1).

Stages II-V. $\quad 55$ Specimens.

Empty (28), "Fish" (18), Gadus minutus (2), G. merlangus (2), Clupeoids (4), Upogebia (1), Carcinus (1).

(b) Males. Stages I and I-II. 50 Specimens.

Empty (43), Mysids (4), Upogebia (2), Larval Gadoids (8).

Stages II-V. $\quad 62$ Specimens.

Empty (43), "Fish" (8), Clupeoids (4), Callionymus sp. (2), Upogebia deltura (1), Squid (1), Nereis sp. (1).

(c) Very Average size 33 Specimens.

small. $\quad 12 \cdot 4 \mathrm{cms}$. All with larval gadoids.

(Gadus minutus and merlangus.)

* "Fish" denotes unidentifiable fish remains. 